\title{
COPPER, IRON AND ZINC CONTENTS IN WATER, PAKCOY(Brassica rapa L.)AND TILAPIA (Oreochromis niloticus) IN THE PRESENCE OF AQUAPONICS
}

\author{
Deswati*, H. Suyani, A. K. Muchtar, E. F. Abe, Y. Yusuf and H. Pardi \\ Department of Chemistry, Faculty of Mathematics and Natural Science, Andalas University, \\ Kampus Limau Manis, Padang, 25163 Indonesia \\ *E-mail: deswati@sci.unand.ac.id,deswati_ua@yahoo.co.id
}

\begin{abstract}
This research analyzes the effects of the use of aquaponics on the metal contents $(\mathrm{Cu}, \mathrm{Fe}$ and $\mathrm{Zn})$ in water, pakcoy, and tilapia. Fish and plant sampling techniques were conducted randomly while the water sampling was taken at three points: the fish pond, the tank after biofiltering, and the hydroponic tank. Sampling was done 4 times, for 0 , 10, 20 and 30 days. The method of wet destruction with aquaregia was used for the preparation of the fish and plant samples. Furthermore, the content of $\mathrm{Cu}, \mathrm{Fe}$ and $\mathrm{Zn}$ metals in water, pakcoy and tilapia was detected using flame atomic absorption spectrophotometer (FAAS). The results showed that the concentrations of $\mathrm{Cu}, \mathrm{Fe}$ and $\mathrm{Zn}$ metals were higher on the $10^{\text {th }}$ day than on the 0 days. But after the $20^{\text {th }}$ day and the the $30^{\text {th }}$ day, the concentrations of $\mathrm{Cu}$, $\mathrm{Fe}$ and $\mathrm{Zn}$ in the pond water were reduced. The concentrations of $\mathrm{Cu}, \mathrm{Fe}$ and $\mathrm{Zn}$ metals in the fish pond were $0.008 \mathrm{mg} / \mathrm{L}, 0.44 \mathrm{mg} / \mathrm{L}$ and $0.309 \mathrm{mg} / \mathrm{L}$ respectively on the $30^{\text {th }}$ day. According to the Government Regulation Number 82 of 2001, the standard of water quality for fish and plant cultivation for $\mathrm{Cu}, \mathrm{Fe}$ and $\mathrm{Zn}$ concentrations are $0.02 \mathrm{mg} / \mathrm{L}, 0.3 \mathrm{mg} / \mathrm{L}$ and $0.05 \mathrm{mg} / \mathrm{L}$ respectively. It was therefore resolved that the $\mathrm{Cu}$ metal concentrations obtained has satisfied the standard of water quality, while the concentrations of Fe and $\mathrm{Zn}$ metals did not attain the alleged standard of water quality. The highest level of $\mathrm{Cu}$ metal in the tilapia fish (Oreochromis niloticus) was $22.94 \mathrm{mg} / \mathrm{kg}$ and this was ascertained on the $20^{\text {th }}$ day. The highest level of $\mathrm{Zn}$ concentration on day 0 was $157.10 \mathrm{mg} / \mathrm{kg}$. Similarly, the highest level of Fe content on the $30^{\text {th }}$ day was $826.91 \mathrm{mg} / \mathrm{kg}$. On the other hand, the highest level of $\mathrm{Cu}$ content in the pakcoy plant was $27.82 \mathrm{mg} / \mathrm{kg}$, the highest level of $\mathrm{Zn}$ content was $210.81 \mathrm{mg} / \mathrm{kg}$ and the highest level of Fe content was $2583.61 \mathrm{mg} / \mathrm{kg}$ and this was detected in the analyzed samples on the $30^{\text {th }}$ day. The study shows that the content of the $\mathrm{Cu}$ and $\mathrm{Zn}$ levels in the tilapia and pakcoy plants have exceeded the national standard limit according to Decree of the Director General of Drugs and Food Control POM/03725/B/SKVII/89.
\end{abstract}

Keywords : Aquaponics, metal contents, Biofiltering, hydroponics

(C) RASĀYAN. All rights reserved

\section{INTRODUCTION}

Indonesia has extensive agricultural lands with most of its populace being predominantly farmers. Some of the farmers are into the fishery and this is evident by their numerous fish ponds and fish cultivation techniques. But until recently, most of the lands used for agricultural purposes are being used by the government for roads, erection of modern markets, housing and other public facilities. These activities by the government continue to increase as the population increases and as a result, the lands used for agricultural purposes keeps decreasing.

However, with the emergence of science and technology, a solution has been found. This solution utilizes a combination of aquaculture and hydroponics to sustain fishes and plants in an integrated system and this is known as an aquaponic system ${ }^{1-2}$. The aquaponics system has numerous advantages such as conserving energy, producing organic fertilizers for plants, conservation of water and eradication of waste products. The aquaponics system, deals with a process known as aquaculture. Aquaculture is the process of recycling. For instance, the water used is continuously passed through the filtration process in order to overcome the deterioration of the quality of the water used in the system ${ }^{3}$. The $\mathrm{pH}, \mathrm{DO}$ and COD

Rasayan J. Chem., 12(1), 40-49(2019)

http://dx.doi.org/10.31788/RJC.2019.1215062

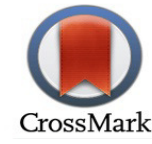


parameters of the water must be maintained, in order not to interfere with the growth of the fishes, bacteria and plants. Waste water, contain nutrients such as ammonia $\left(\mathrm{NH}_{3}\right)$, nitrite $\left(\mathrm{NO}_{2}\right)$, nitrate $\left(\mathrm{NO}_{3}\right)$, phosphate $\left(\mathrm{PO}_{4}\right)$ and micro essential metals. These nutrients can be absorbed by plants in hydroponic media, thereby causing the water to be free of waste and this water can be re-channeled to the aquaculture media $^{1}$. During the process of the waste water purification stage, the nitrifying bacteria play an important role in the oxidation of ammonia into nitrates and these nutrients are needed by the plants ${ }^{4}$.

The fish cultivated in the aquaponic system is tilapia. Tilapia is a freshwater fish that is widely cultivated because of its high tolerance to environmental changes, such as high water temperature, low oxygen concentration and the presence of excess ammonia.Fishes have an excellent nutritional quality because of its high protein content ${ }^{5}$. Micro essential elements such as $\mathrm{Cu}, \mathrm{Zn}$ and $\mathrm{Fe}$ derived from pellets play an important role in the growth of fishes. $\mathrm{Cu}$ and $\mathrm{Zn}$ metals are needed by aquatic organisms for their physiological and morphological growth, development and reproduction. Fe metal is the main constituent of hemoglobin, myoglobin and several enzymes ${ }^{6}$.

In the hydroponic circuit, other planting media are used in place of soil. The rockwool is a planting medium. Studies have shown that mustard (Brassica juncea L.) plants planted on rockwool developed well especially in height and color unlike those planted in the wood powder and rice husk media. This is because the rockwool has a smooth, soft particle substrate, and a good drainage system, thereby, enabling the roots of the plant to easily absorb water ${ }^{7}$.

The hydroponic plants used are pakcoy vegetables (Brassica rapa $\mathrm{L}$ ). These vegetables have high nutritional and economic values. They can grow anywhere (highlands and lowlands) and their growth is not dependent on weather conditions making them suitable crops for the hydroponic systems ${ }^{8}$. Pakcoy vegetables require essential micro nutrients such as $\mathrm{Cu}, \mathrm{Zn}$ and $\mathrm{Fe}$ metals. These essential nutrients are gotten from the reminants of the fish feed or decomposed organic compounds. It is therefore of paramount importance to provide sufficient feed for the development of the fishes and enough nutrients for the growth of the pakcoy plants.

In plants, the $\mathrm{Fe}$ metal plays an important role in the formation of chlorophyll, the $\mathrm{Cu}$ metal is also a constituent of enzymes, chlorophyll and it also aids in the metabolism of carbohydrates and proteins. The $\mathrm{Zn}$ metal is involved in several enzyme functions such as increasing the rate of metabolic reactions; it also synthesizes plant growth, produces chlorophyll and carbohydrates ${ }^{9}$. Essential metals are needed in small quantities or concentrations. Increased concentration of essential metals could cause poisoning in plants, living things in water and also to humans who consume such products ${ }^{10}$.

Excessive consumption of $\mathrm{Cu}$ metal causes several mental and neurological diseases such as schizophrenia, depression, autism, tardive dyskinesia and memory loss. Kidney failure, liver abnormalities, hypertentionand skin aging could also be affected by the excessive consumption of $\mathrm{Cu}$ metal . Toxicity of Fe metal in the body causes damage to the liver, heart and lungs. It also causes diabetes mellitus, hormonal abnormalities and immune system dysfunction ${ }^{11}$. Excess $\mathrm{Zn}$ in the body causes mental disorder and reduced focal activity. This research work is based on the analysis of heavy metals $(\mathrm{Cu}, \mathrm{Fe}, \mathrm{Zn})$ on water, pakcoy (Brassica rapa L.) and Tilapia (Oreochromis niloticus) in the aquaponics system.

\section{Instruments and Materials}

\section{EXPERIMENTAL}

The equipment used in this study are FAAS (Flame Atomic Absorption Spectroscopy), pH meter, DO meter, fish pond, water tank, PVC pipe, aerator, netpot, oven, desiccators, analytical balance, brown reagent bottle, kjeldahl pumpkin, hot plate and glasswares that are commonly used in the laboratories.

The materials used in this study are fish feed, vegetable seeds, rockwool planting medium, 1000 fishes (8$10 \mathrm{~cm}$ ), $6 \mathrm{~m}^{3}$ of water, $\mathrm{K}_{2} \mathrm{Cr}_{2} \mathrm{O}_{7}$ solution, $0.01 \mathrm{~N} \mathrm{KMnO}_{4}$ solution, $0.01 \mathrm{~N} \mathrm{Na}_{2} \mathrm{~S}_{2} \mathrm{O}_{3}$, doubly distilled water, $\mathrm{H}_{2} \mathrm{SO}_{4} 4 \mathrm{~N}, \mathrm{HCl} 2 \mathrm{~N}$, mother liquor ( $\mathrm{Zn} 1000 \mathrm{mg} / \mathrm{L}$, Fe $1000 \mathrm{mg} / \mathrm{L}$ and $\mathrm{Cu} 1000 \mathrm{mg} / \mathrm{L}$ ).

\section{Research Procedure}

\section{Aquaponics System Preparation}

The aquaponic system consists of a fish pond that has a diameter of $300 \mathrm{~cm}$ and height of $100 \mathrm{~cm}$, sediment filter tanks $\left(150 \mathrm{dm}^{3}\right)$, bio-media tanks $\left(150 \mathrm{dm}^{3}\right)$, filtration water tanks $\left(150 \mathrm{dm}^{3}\right)$ and 
hydroponic circuits. The fish pond is filled with $6 \mathrm{~m}^{3}$ of water, 1000 fishes were then put into it and the pond was protected with a transparent roof.

Water from the fish pond was connected to the sediment filtering tank, and from there it was also connected in such a way that it flowed into the bio-media tank and then to the water tank. The water from the filtration tank was channeled to the hydroponic circuit. The water from the hydroponic circuit was then collected in the water tank and then made to flow back into the fish pond. The water flow in the fish pond is regulated by the oxygen consumption while the oxygen demand in the water is regulated by the aerator. Figure-1 shows the aquaponic system scheme.

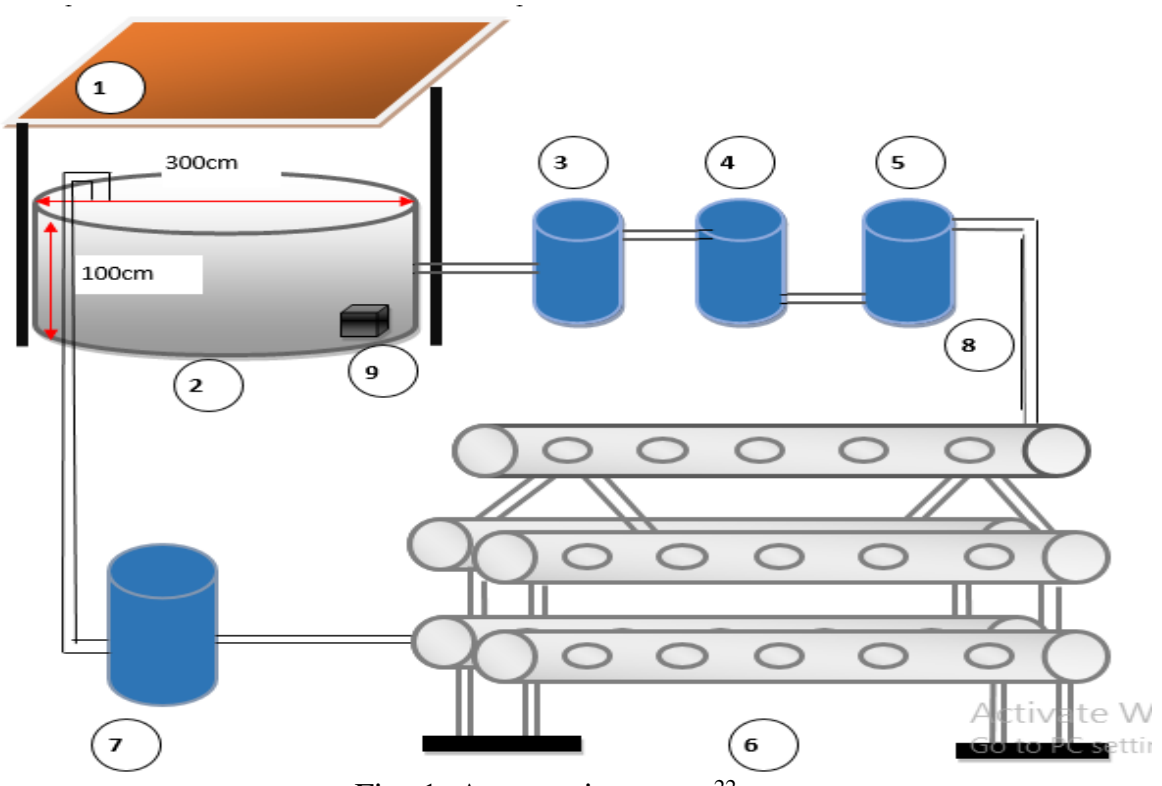

Fig.-1: Aquaponic system ${ }^{22}$

\section{Information :}

1. Roof

3. Pond Water Container Tank

5. Waterfall Tank of biofilter

7. Water holding tank from the hydroponic circuit

8. Pipe

\section{Planting Media Preparation}

The medium used for planting is the rockwool. A rockwool size of about $40 \times 30 \mathrm{~cm}$ was used and it was cut into $1 \times 1 \mathrm{~cm}$ in order to facilitate the transfer of seeds from the nursery to the netpot. The pakcoy seeds were then sown for 1 week before they were transferred to the hydroponic circuit.

\section{Aquaponics System Analysis}

The analysis and measurements of several parameters were carried out for 0,10, 20 and 30 days.(1) some parameters supporting the quality of the water such as the $\mathrm{pH}$, DO and COD, (2) The height and number of leaves on the plant, (3) the length and weight of the fishes, and (4) the metals $\mathrm{Cu}, \mathrm{Zn}$, and $\mathrm{Fe}$.

\section{Metal Content Analysis (Cu, Zn, Fe)}

The analysis of the metal contents in plants was carried out using the FAAS tools. Before conducting a sample analysis with FAAS, a sample preparation step was carried out in order to release the metal bonds from other compounds so that the metal elements were now in a free state making it possible for it to be read on the device. The sample preparation method is a destructive method that can reduce organic compounds and separate ions so that they do not interfere with the metal analysis ${ }^{12}$. In this study, the wet destruction method was used because of the short time duration. A low temperature was used and the 
probability of losing elements was minimal. Wet destruction was carried out using kjeldahl flask and the dry sample obtained was dissolved in aqua regia solvent or a mixture of concentrated hydrochloric acid and concentrated nitric acid with a ratio of about $3: 1$ and then heated to a temperature of about of $\pm 60^{\circ} \mathrm{C}$. The destruction process can be stopped once the solution is clear; this indicates that the organic compounds in the sample have been completely broken down. The solution was then diluted in a $50 \mathrm{ml}$ measuring flask and then filtered with a Whatman paper No.42 (pore size $0.45 \mu \mathrm{m}$ ).

\section{Water Quality Analysis \\ pH}

\section{RESULTS AND DISCUSSION}

In the aquaponic system, the $\mathrm{pH}$ value of the water is very important for the growth and survival of the fishes and plants. The ideal $\mathrm{pH}$ of water in fish ponds is 7.8. Fishes can also survive if the $\mathrm{pH}$ ranges from 6-8.5 ${ }^{13}$. The average $\mathrm{pH}$ of water in the tank after the filtration process was 7.9. This depicts that the $\mathrm{pH}$ of the water was good for bacterial growth because the optimum $\mathrm{pH}$ for bacteria growth is between $6-8.5$. The $\mathrm{pH}$ of water in the tank after hydroponics was 8 . According to toto ${ }^{13}$, the standard $\mathrm{pH}$ for plant growth is $5.5-7.5$; this implies that the $\mathrm{pH}$ of water in the hydroponic system exceeded the optimum $\mathrm{pH}$. Furthermore, this condition affects the availability of the plant nutrients.If the $\mathrm{pH}$ of the water is $\geq 7.5$ this implies that there is a reduction in the nutrition available (Fig.-2).

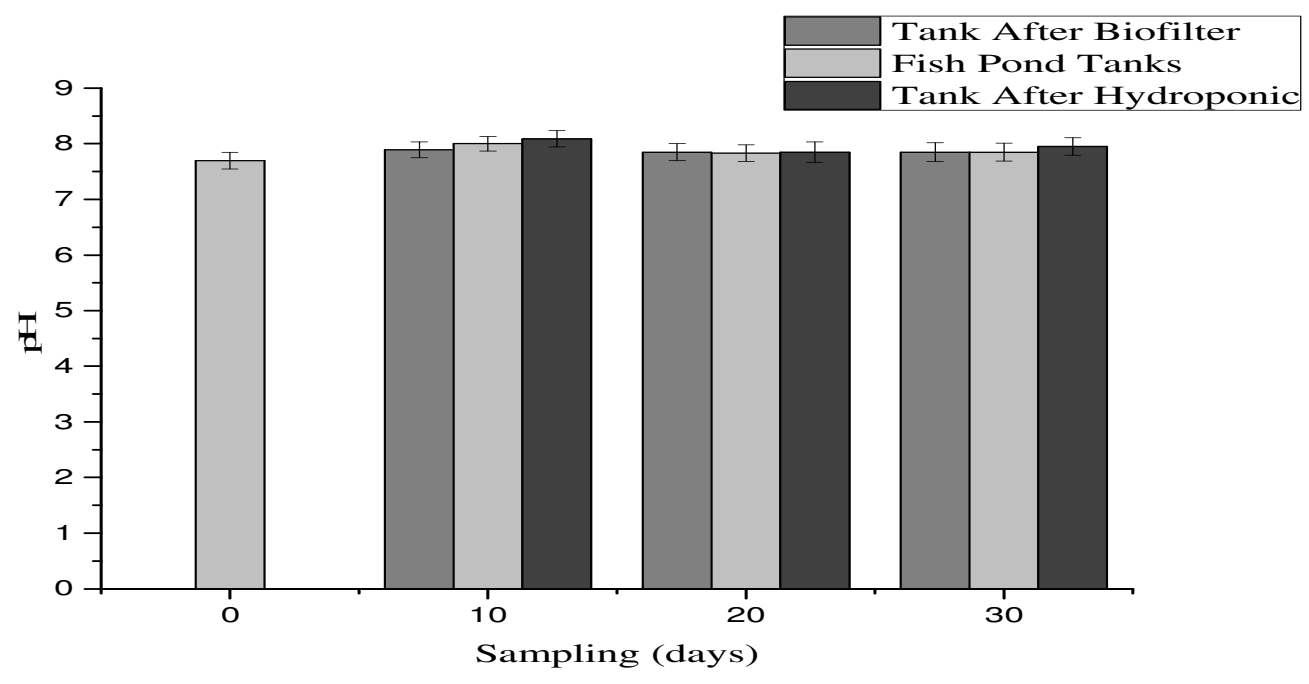

Fig.-2: $\mathrm{pH}$ in different sampling time (days)

DO is another parameter that is used to determine the sustainability of the aquaponics system. DO values in the fish ponds for 10 to 30 days was $2 \mathrm{mg} / \mathrm{L}$ which was smaller than the optimal DO ( 4-6 mg/L for fish cultivation $)^{13}$. If the $\mathrm{DO}$ value is $<4 \mathrm{mg} / \mathrm{L}$, fishes can still survive in ponds but their growth is minimal. Reduction in the DO levels in water is caused by the decomposition of the organic materials in the water. Organic materials containing nitrogen will produce ammonia after the decomposition. Low oxygen levels are not enough to convert ammonia, so in anaerobic conditions, ammonia is toxic to the fishes and it caused 40 of the fishes to die. DO levels in the tank after passing the biofilter was $3.06 \mathrm{mg} / \mathrm{L}$ (Fig.-3).

Plant growth is also affected by the DO levels. DO level in the tank after the hydroponics process was found to be $3.2 \mathrm{mg} / \mathrm{L}$. The recommended DO level for hydroponic plant growth $>3 \mathrm{mg} / \mathrm{L}$, This depicts that the DO for thepakcoy plant is still in optimal condition. In this study fungi and mildew was found to be stuck at the roots of the plant. This problem is often encountered by vegetable farmers, and normally the fungus grows if the conditions are moist. The roots of the pakcoy plants are readily attacked by irregular pythium fungi. This fungus causes the roots of the plant to rot. The mosses attached to the roots where from the fish pond. This depicts that the filter used did not function optimally. The COD value of the pond water on day 0 was $6.098 \mathrm{mg} / \mathrm{L}$, and on the $10^{\text {th }}, 20^{\text {th }}$ and $30^{\text {th }}$ days were $(6.208 ; 9.523$; and 
RASĀYAN J. Chem.

Vol. 12 | No. 1 | 40 - 49| January - March | 2019

$6.829) \mathrm{mg} / \mathrm{L}$, respectively. From day 0 to 20 the values of the COD in the pond increased, as a result of the increasing number of organic materials derived from the remaining feed and fish stools that accumulated in the pond. On the $30^{\text {th }}$ day the COD value in the pond decreased because som e of the organic materials from pond water was broken down into inorganic materials. The values of the COD of the water in the tank after passing through the biofilter on the $10^{\text {th }}, 20^{\text {th }}, 30^{\text {th }}$ days were $(5.743 ; 9.293$ and $6.674) \mathrm{mg} / \mathrm{L}$ respectively.

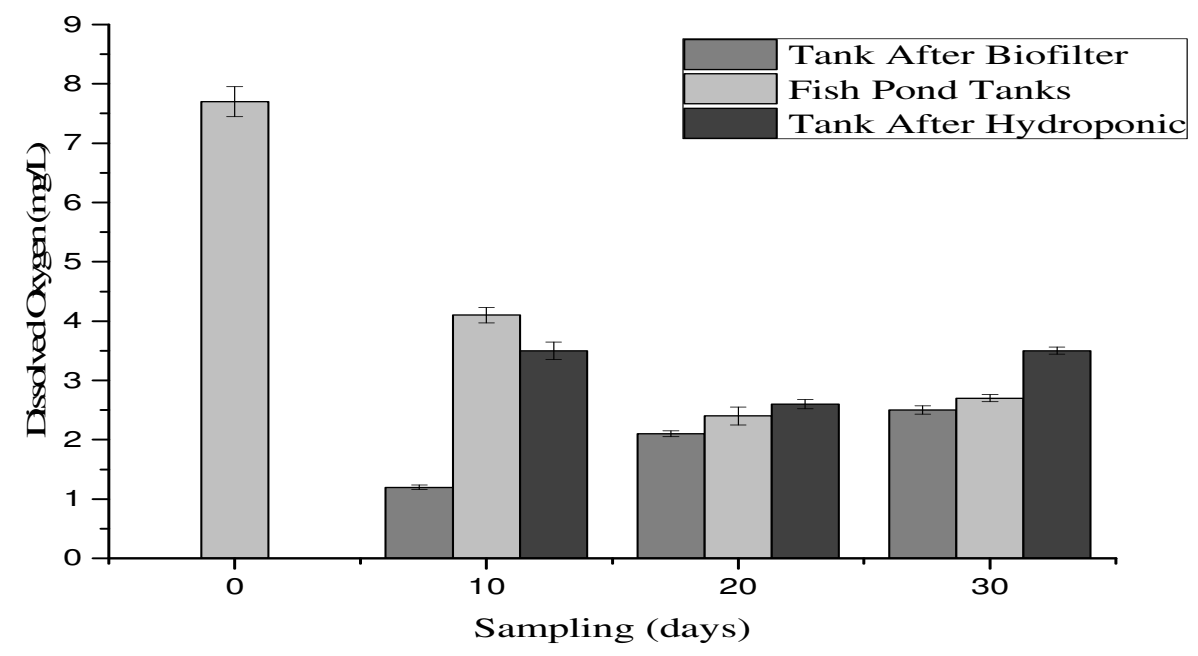

Fig.-3: DO (mg/L) in different sampling time (days)

This condition occurred because some of the organic substances have been converted into inorganic substances by the bacteria in the biofilter tank, so it takes less $\mathrm{O}_{2}$ to oxidize the organic substances in the tank after going through biofilter ${ }^{13}$. Whereas the COD values after passing through the hydroponic circuit on the $10^{\text {th }}, 20^{\text {th }}$ and $30^{\text {th }}$ days in a row were $(6.829 ; 10.174 ; 6.208) \mathrm{mg} / \mathrm{L}$ respectively, and this condition occurred due to the presence of the decaying roots in hydroponic plants (Fig.-4).

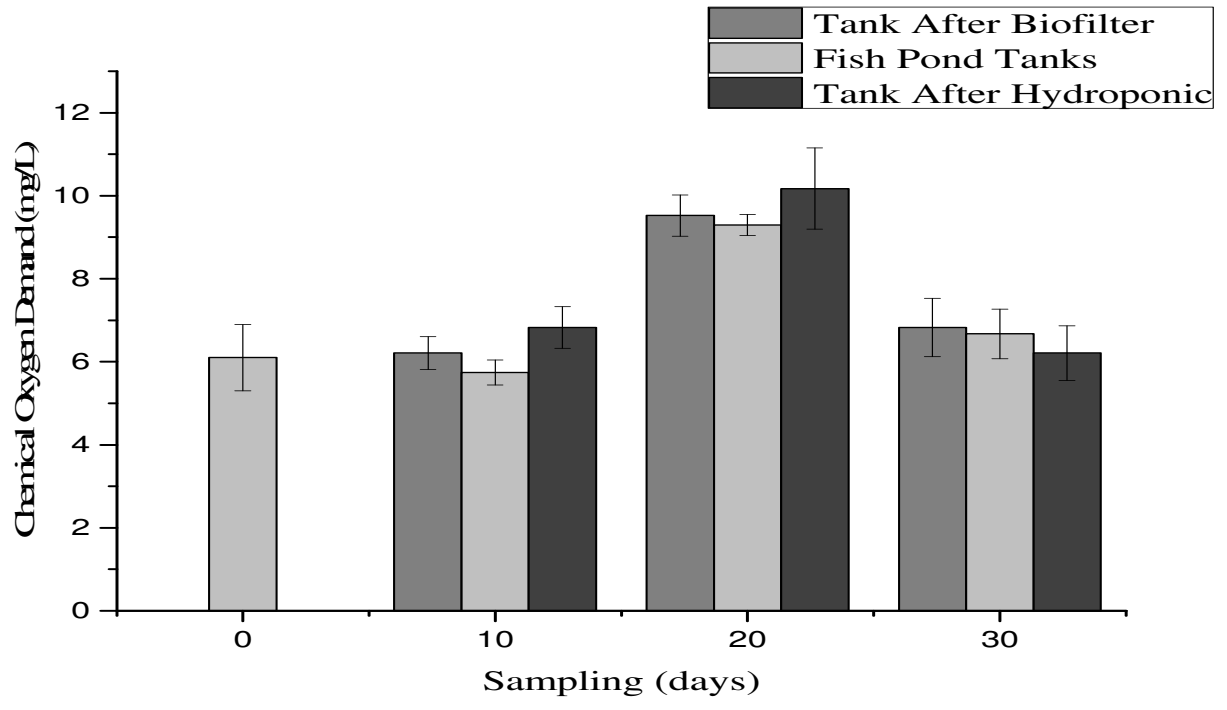

\section{Analysis of Plant and Fish Growth \\ Plant Growth}

Fig.-4: COD (mg/L) in different sampling time (days)

This was done by taking the measurements of the plant height and the number of leaves on the plants was calculated for 30 days with a measurement range of $0,10,20$ and 30 days. We can see the height of the 
pakcoy plant and the number of leaves on it from day 0 to day 30 in Figure 5 . On the $30^{\text {th }}$ day, there was no increase in the height of the plant and the number of leaves as a result of a large number of metal ions absorbed by the plant. Some of the leaves turned yellow and died as a result of lack of nutrients such as nitrogen and magnesium which play an important role in the formation of chlorophyll.

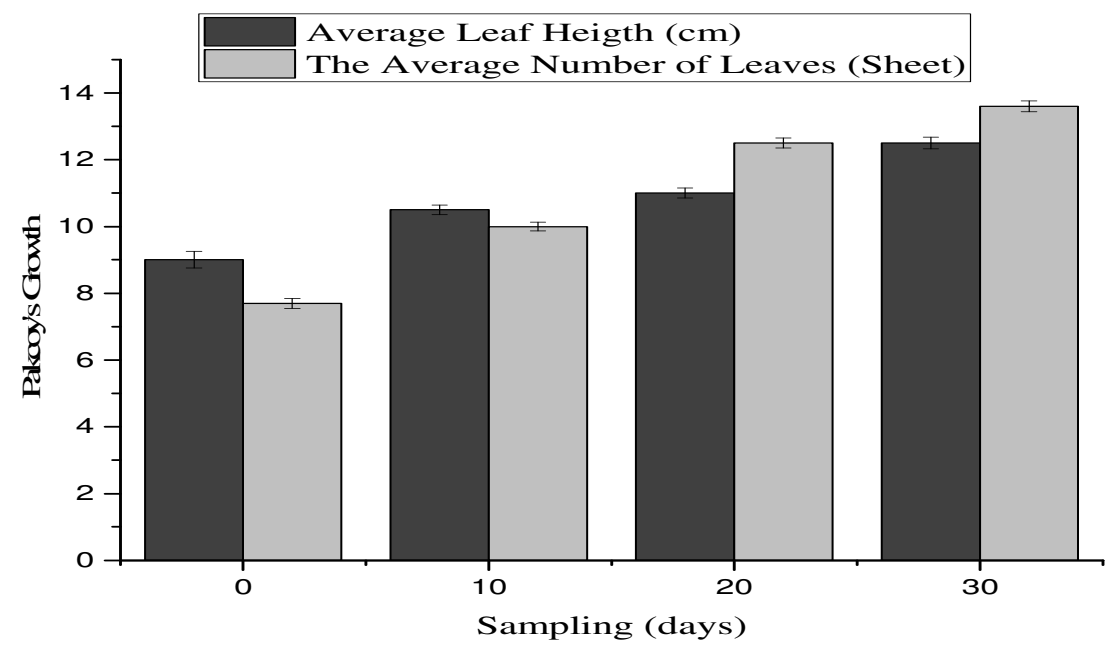

Fig.-5: Plant growth (height $(\mathrm{cm})$ and number of leaves (sheet)) in different sampling time (days)

\section{Fish Growth}

40 random samples were taken by measuring the weight and length of the fishes on days 0,10,20 and 30 can be seen in Figure 6. The fishes were fed 3\% of their body weight, twice daily. The reminants of the fish feed settled at the bottom of the pond thereby increasing the level of the organic compounds and ammonia. This affects the growth of the fishes. The high content of ammonia in the pond, causes fishes to have difficulty in breathing, dizziness and eventually causes death. This was depicted by the death of the fishes in the pond after the $20^{\text {th }}$ day of the aquaponics system. Low levels of DO on the $10^{\text {th }}, 20^{\text {th }}$ and $30^{\text {th }}$ days consecutively were $(1.2 ; 2.1$, and 2.5$) \mathrm{mg} / \mathrm{L}$. They were among the factors that caused mass mortality of fishes. Dead tilapia generally floated on the surface of the water, looking slimmer, with more prominent eyes, bloated stomach, and their mouths opened.

\section{Analysis of Cu Metal}

The data obtained, showed that the concentration of the $\mathrm{Cu}$ in the fish pond tank on day 0 was 0.005 $\mathrm{mg} / \mathrm{L}$, the concentration of $\mathrm{Cu}$ was lower on the $10^{\text {th }}$ day $0.017 \mathrm{mg} / \mathrm{L}$. This was because on the 0th day the aquaponics system was not yet operational. However, after the $20^{\text {th }}$ and $30^{\text {th }}$ days, the concentration of $\mathrm{Cu}$ in the fish pond tank decreased to $(0.009$, and 0.008$) \mathrm{mg} / \mathrm{L}$.

Figure-7, there was a decrease in the concentration of the $\mathrm{Cu}$ metal after it was passed through the biofilter. This was caused by the pumice in the biofilter tank. This pumice functions as an adsorbent that absorbs the $\mathrm{Cu}$ metal ${ }^{14}$. Furthermore, the concentration of the $\mathrm{Cu}$ metal, increases after passing through the hydroponic circuit. This is because the $\mathrm{Cu}$ is a micro nutrient for plants. However, there is high availability of this element in the solution and this causes some of the $\mathrm{Cu}$ metals to be absorbed directly by the plants as nutrients. Some of the $\mathrm{Cu}$ metals got attached to the roots of the plants and this was dissolved by the water causing an increase in the concentration of the metal ${ }^{15}$.

According to the Government Regulation Number 82 of 2001, the $\mathrm{Cu}$ metal concentration threshold for class II water quality classification in fish and plant cultivation systems is $0.02 \mathrm{mg} / \mathrm{L}$. When viewed in Figure 7, the data of $\mathrm{Cu}$ metal concentration on the $30^{\text {th }}$ day, the $\mathrm{Cu}$ metal concentration obtained was $<0.02 \mathrm{mg} / \mathrm{L}$. This depicts that the aquaponics system was able to reduce the concentration of the $\mathrm{Cu}$ concentration in water and also met the standards of the water quality.

Heavy metals can get into the fishes' body through food and water consumed. This can harm the body of the fishes because of its tendency to accumulate in their bodies ${ }^{16}$. Cu metal content in the fishes for 0,10 , 
RASĀYAN J. Chem.

Vol. 12 | No. 1 | 40 - 49| January - March | 2019

20 and 30 days were $(9.37 ; 10.23 ; 22.94$ and 10.58$) \mathrm{mg} / \mathrm{Kg}$, respectively. According to the Decree of the Director General of Drug and Food Control, POM/03725/B/SKVII/89, the levels of $\mathrm{Cu}$ in fishes on days $0,10,30$ were still below the maximum limit of $20 \mathrm{mg} / \mathrm{Kg}$, but on the $20^{\text {th }}$ day, the $\mathrm{Cu}$ levels exceeded the maximum limit so they were not suitable for consumption.

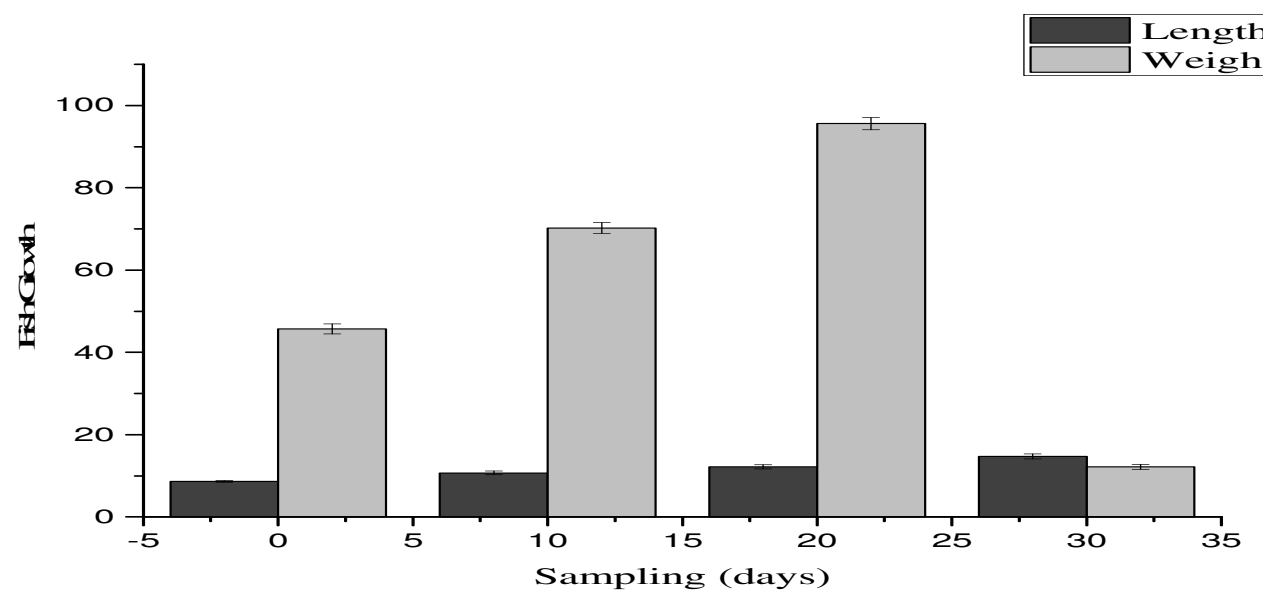

Fig.-6: Fish growth (length $(\mathrm{cm})$, weight $(\mathrm{g})$ in different sampling time (days)

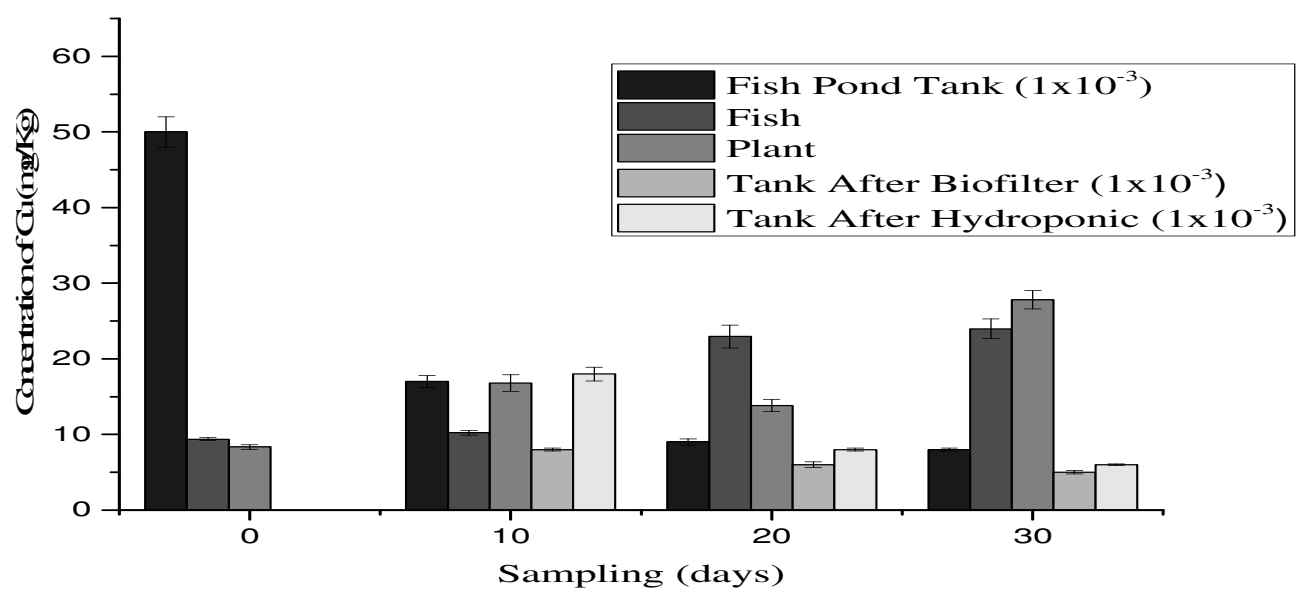

Fig.-7: $\mathrm{Cu}$ content $(\mathrm{mg} / \mathrm{Kg})$ in water samples to different sampling time (days)

Figure-7, the $\mathrm{Cu}$ content of plants from day 0-10 increased to $16.79 \mathrm{mg} / \mathrm{Kg}$. This shows the maximum absorption of metals by the plant roots. On the $20^{\text {th }}$ day, the $\mathrm{Cu}$ metal content decreased to $13.83 \mathrm{mg} / \mathrm{Kg}$, due to a disturbance in the absorption of the nutrients by the plant roots, and this was thought to be influenced by the plant roots covered by mold and mildew. On the $30^{\text {th }}$ day, the $\mathrm{Cu}$ metal content increased again to $27.8247 \mathrm{mg} / \mathrm{kg}$, and this was influenced by the cutting process of the plant roots. In order to eliminate the influence of the presence of mosses and fungi on the absorption of nutrients in the roots, the roots were cut. According to toto ${ }^{17}$, cutting the roots of the plant can increase the surface area, diameter and weight of the plant roots. Cutting of the root tip causes an increase in the lateral root growth. The growth of the lateral roots increases the number of roots so that uptake of nutrients is maximized. The content of $\mathrm{Cu}$ metal in pakcoy plants on days $0,10,20,30$ is still within safe limits according to the Decree of the Director General of Drug and Food Control, POM/03725/B/SKVII/89.

\section{Analysis of Zn Metal}

$\mathrm{Zn}$ data in fish ponds on days 0 and 10 respectively were $(0.21$, and 0.683$) \mathrm{mg} / \mathrm{L}$. The concentration of $\mathrm{Zn}$ metal on the $10^{\text {th }}$ day was higher than the concentration on day 0 , because on day 0 the aquaponics 
RASĀYAN J. Chem.

Vol. 12 | No. 1 |40 - 49| January - March | 2019

system was not yet operational. However, after the $20^{\text {th }}$ and $30^{\text {th }}$ days, the concentration of the $\mathrm{Zn}$ metal in pond water decreased to $(0.532$, and 0.309$) \mathrm{mg} / \mathrm{L}$.

Figure-8, shows that there was a decrease in the concentration of $\mathrm{Zn}$ metal after the water was passed through the biofilter tank on the 10th, 20th and $30^{\text {th }}$ days. This was as a result of the filtration by the pumice in the biofilter tank ${ }^{14}$, but there was an increase in the concentration of $\mathrm{Zn}$ metal after it had passed through the hydroponic circuit. This is because the $\mathrm{Zn}$ metal is a micro nutrient for plants. The availability of this element is high in solutions. Some $\mathrm{Zn}$ metals are absorbed directly by plants as nutrients, while some metals get attached to the root micelles of the plants and dissolves when the water flows leading to an increase in the concentration of the $\mathrm{Zn}$ metal ${ }^{15}$. When the $30^{\text {th }}$-day data was compared with the previous day's data, the aquaponics system was able to reduce the $\mathrm{Zn}$ metal concentration. However, according to the Government Regulation Number 82the the year 2001, for class II water quality classification, the concentration of $\mathrm{Zn}$ metals appropriate in fishes and plants cultivation systems is 0.05 $\mathrm{mg} / \mathrm{L}$ which is above the threshold value. The factors that cause the pakcoy plants to absorb the $\mathrm{Zn}$ metal are minimal because the numbers of pakcoy plants are less than the metal that is absorbed.

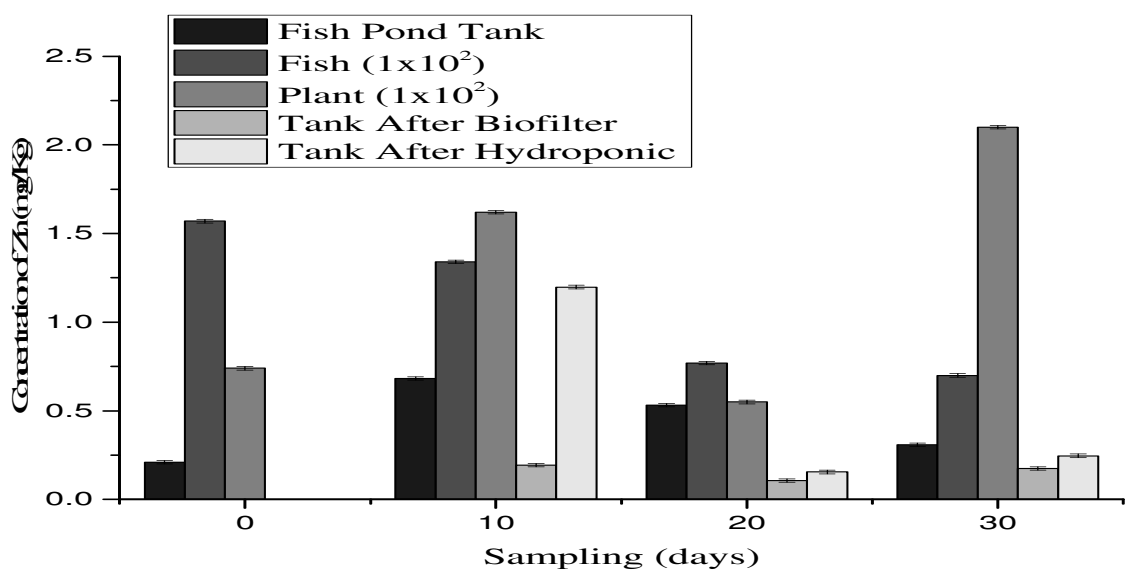

Fig.-8: $\mathrm{Zn}$ content $(\mathrm{mg} / \mathrm{Kg})$ to different sampling time (days)

$\mathrm{Zn}$ is a micro nutrient needed by living things. In plants, $\mathrm{Zn}$ plays a major role in increasing metabolic reactions, synthesizing plant growth, producing chlorophyll and carbohydrates ${ }^{18}$. $\mathrm{Zn}$ metal content in the plant is the same as the $\mathrm{Cu}$ metal content which increased on the $10^{\text {th }}$ day from (74.4256 to 162.6059) $\mathrm{mg} / \mathrm{Kg}$ and decreased swiftly on the $20^{\text {th }}$ day to $55.3471 \mathrm{mg} / \mathrm{Kg}$. After cutting the roots of the plants, there was an increase in the absorption of $\mathrm{Zn}$ on the $30^{\text {th }}$ day and this reached $210.812 \mathrm{mg} / \mathrm{Kg}$. From the data obtained, the absorption of $\mathrm{Zn}$ metal by plants is greater than $\mathrm{Cu}$. $\mathrm{Zn}$ metal content on days 0, 10, 20 and 30 exceeded the maximum limit of more than $40 \mathrm{mg} / \mathrm{Kg}$ according to the Decree of the Directorate General of Drug and Food Control: POM/03725/B/SKVII/89

$\mathrm{Zn}$ metal content in the fishes on days $0,10,20$ and 30were as follows $(157.0937 ; 134.7549 ; 70.2382$; 77.0944) $\mathrm{mg} / \mathrm{Kg}$, respectively.Based on the Decree of the Directorate General of Drug and Food Control: $\mathrm{POM} / 03725 / \mathrm{B} / \mathrm{SKVII} / 89$ the fishes on the $20^{\text {th }}$ and $30^{\text {th }}$ days are safe for consumption, while the fishes on the 0 and 10 days are not safe for consumption because $\mathrm{Zn}$ levels exceed the allowed quality standards.

\section{Analysis of Fe Metal}

The concentration of Fe metal in the pond on day 0 was $1.474 \mathrm{mg} / \mathrm{L}$, and on the $10^{\text {th }}$ day the concentration of Fe metal increased to $5.727 \mathrm{mg} / \mathrm{L}$. There was an increase in the concentration of the Fe metal because on day 0 the aquaponics system was not yet functional. However, after 20 and 30 days the concentration of Fe metal in the pond decreased significantly to $(0.613$ and 0.44$) \mathrm{mg} / \mathrm{L}$, due to the need of Fe metal for plant growth.

The concentration of the Fe metal was decreased after the water was passed through the biofilter (Fig.-9). This is due to the absorption or the filtration process of the metal by the mineral stones in the biofilter 
$\operatorname{tank}^{19}$.There was an increase in the concentration of the Fe metal after the water was passed through the hydroponic circuit. This occurred as a result of the high availability of Fe metal in the solution, so that some of the metal was directly absorbed by plants, while others got stuck to the root micelles of the plant, thereby leading to an increased concentration of the Fe metal when water is passed through $\mathrm{it}^{15}$. When compared between the 30-day data and the previous day's data, it was deduced that the aquaponics system was able to reduce the concentration of the Fe metal in the water. However, the concentration of metal did not meet the standard of the water quality in accordance with Government Regulation Number 82 of 2001 , for class II water quality classification in fishes and plants cultivation systems, which is $0.3 \mathrm{mg} / \mathrm{L}$.

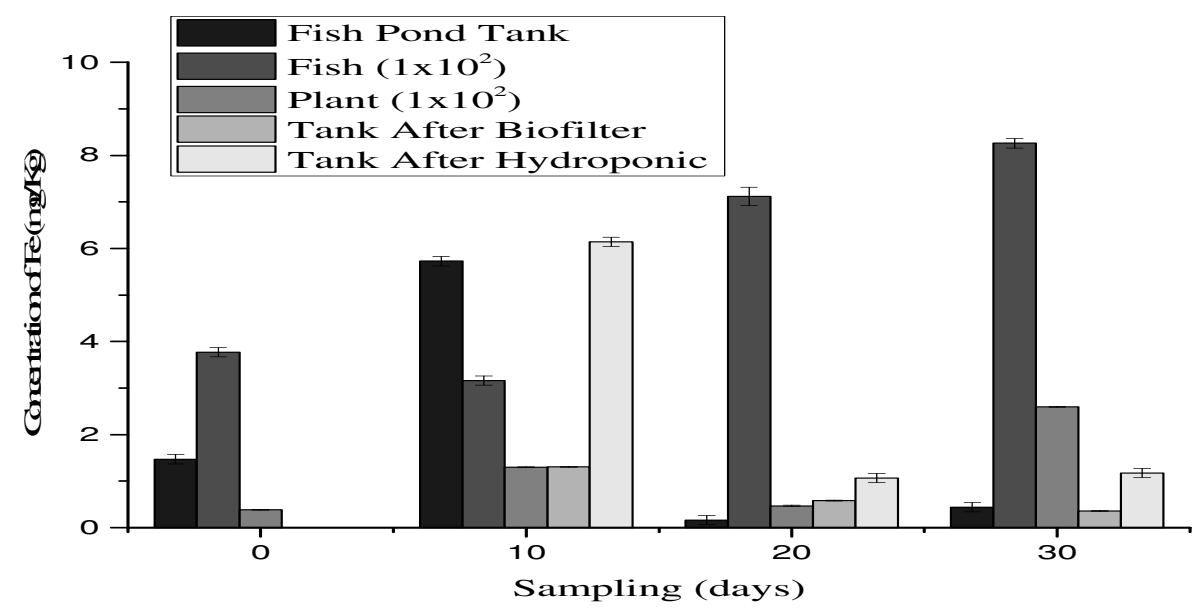

Fig.-9: Fe content (mg/Kg) into different sampling time (days)

The results of the Fe content analysis of the aquaponics cultured fishes on days 0, 10, 20 and 30 were $(377.8342 ; 316.288 ; 712.4598 ; 826.9072) \mathrm{mg} / \mathrm{kg}$ respectively. Based on the Decree of the Director General of Drug and Food Control, POM/03725/ B/SKVII/89 the levels of Fe metal in fishes and its processed products are not limited because they are badly needed by the body. Fe is an essential metal that plays a major role in the formation of chlorophyll. Its levels in plants must be in an optimal state so that the formation of chlorophyll will be perfect. The Fe content in thepakcoy plants on day 0 was $387.6688 \mathrm{mg} / \mathrm{Kg}$, this indicated that the content in the plants was quite high and needed a lot of Fe. On the $10^{\text {th }}$ day the Fe content increased to $1,286.8173 \mathrm{mg} / \mathrm{Kg}$ and on the $20^{\text {th }}$ day the Fe content decreased to $475.0047 \mathrm{mg} / \mathrm{Kg}$. This occurred because of the presence of the attached roots, which increased swiftly on the $30^{\text {th }}$ day to $2,583.6125 \mathrm{mg} / \mathrm{Kg}$. The increase in metal on the $30^{\text {th }}$ day was affected by the cutting of plant roots

According to the Decree of the Director General of Drug and Food Control, POM/03725/B/SKVII/89 there is no maximum limit on the Fe content for vegetables and their processed products because these essential metals are needed by plants and humans. Increased metals in plants that are far above the threshold, according to the Decree of the Director General of Drug and Food Control, $\mathrm{POM} / 03725 / \mathrm{B} / \mathrm{SKVII} / 89$ can be caused an imbalance of the nutritional production by fish cultivation and the absorption of nutrients by plants ${ }^{20-21}$. In the aquaponics system, there is an imbalance between the size of the fish pond, the amount of the fishes, the number of nutrients and the number of plants that will absorb nutrients. The number of cultivated fishes reaches 1000 in a very large pond, while the number of plants is just 45. This causes excess metal nutrients thereby inhibiting plant growth and also causes the plants to become stunted. The quality of water that is returned to the pond does not get the best in the form of plants that will absorb ammonia and other nutrients.

\section{CONCLUSION}

It can be concluded that: (1) The growth of fishes, plants, and bacteria was disrupted because of the large number of organic materials contained in the system. This was indicated by high COD values and low DO; (2) $\mathrm{Cu}$ content in tilapia fish (Oreochromis niloticus)was below the standard quality, while the $\mathrm{Zn}$ levels exceeded the maximum limit of $100 \mathrm{mg} / \mathrm{kg}$ as determined by the Director General of Drug and 
RASĀYAN J. Chem.

Vol. 12 | No. 1 |40 - 49| January - March | 2019

Food Control, POM/03725/B/SKVII/89; (3) the Cu, Zn, and Fe metals in pakcoy (Brassica rapa $\mathrm{L}$ ) in day 0 were below the standard quality set so that they are suitable for consumption, while the metal contents on the $10^{\text {th }}, 20^{\text {th }}$ and $30^{\text {th }}$ days were above the established standard quality, and (4) Excess metal content in tilapia (Oreochromis niloticus) and pakcoy plant (Brassica rapa L) was influenced by the production of the nutrients from the aquaculture which did not balanced with the number of plants that absorbed the nutrient.

\section{ACKNOWLEDGMENT}

The Authors would like to thank Andalas University, which has funded research on the acceleration of professors with Number: 29/UN.16.17/PP.PGB/LPPM/2018, April 23, 2018.

\section{REFERENCES}

1. S. Diver S. National Centre of Appropriate Technology. Department of Agriculture's Rural Bussiness Cooperative Service, (2006).

2. J. Rakocy, R.L. Nelson, G. Wilson, Aquaponics J., 4, 1(2005).

3. L.A. Helfrich, G. Libey, Department of Fisheries and Wildlife Sciences. Virginia Tech., 28 (2000).

4. J. E. Rakocy, M.P. Masser; T.M. Aquaponics-integrating Fish and Plant Culture, SRAC Publication no. 454. (2006).

5. D. Mochtadi. Protein: Source and Technology. Food and Nutrition Inter-University Center. Bogor Agricultural Institute, (1989).

6. I. A. simionov, V. Cristea, S. Mihai Petrea, E (Bocioc) Sirbu, M.T. Coada, D.S. Cristea, AACL Bioflux., 9, 1 (2016).

7. Warman, Syawaluddin, I. S. Harahap, Agrohita J., 1, 1 (2016).

8. H. Effendi, B.A. Utomo, G.M. Darmawangsa, Ecolab J., 8, 2 (2015).

9. P.F. Adelia, Koesriharti, Sunaryo, J. Plant Production., 1, 3 (2013), 1(3).

10. S. Langard, and M. Costa. Chromium, in: Handbook on the Toxicology of Metals, $4^{\text {th }}$ edition, Nordberg \& Fowler \& Nordberg Elsevier., 33, (2014).

11. S. G. eugen, C. Neagu, A. E. Gurzau, Ecotoxic and Environ. Safety., 56, 3 (2003). DOI: 10.1016/S0147-6513(03)00062-9

12. S. Kristianingrum. Study of Various Samples and Effects Destruction Processes. Yogyakarta State University: Department of Chemical Education., (2012).

13. H. Y. Yildiz, L. Robaina, J. Pirhonen, E. Mente, D. Domínguez, G. Parisi, Water., 9, 13 (2017), DOI:10.3390/w9010013

14. N. Babakhani, M.R. Khorm, S. Sobhanardakani.. Environ Health Eng Management J., 3, 1 (2016).

15. I. Alkorta, J.M. Becerril, C. Garbisu, Environ Health., 2, 25 (2010), DOI: $10.1515 /$ REVEH.2010.25.2.135

16. Tiimub, B. Makimilua, M. A. D. Afua, .American Int J Bio., 1, 1 (2013).

17. D.N.S. Febriani, D. Indradewa, S. Waluyo, Vegetalika J., 1, 1 (2012).

18. S. Ratmini, Opportunities for Increasing Zinc Content in Cereals, Proceedings of the 2014 Suboptimal National Land Seminar., (2014).

19. A. Rahmani, M. Abbasi, I.Z. Kashitarash, Water and Wastewater., 22, 278 (2011).

20. A. Enduta, A. Jusoh, N. Ali, W.B. Wan Nik, A. Hassan. Desalin, Water Treat., 32, 1 (2011), DOI: 10.5004/dwt.2011.2761

21. Indrawati, R. Achmad, H. Suyani, Refilda, H. Pardi, Deswati, Pollution Research., 37, 2 (2018).

22. Deswati, N. Febriani, H. Pardi, Y. Yusuf, H. Suyani, Orient J Chem., 34, 5 (2018), DOI: $10.13005 / \mathrm{ojc} / 340529$

[RJC-5062/2018] 